\title{
低層建物の準静的風荷重の組合せに対する周辺建物群の影響 EFFECTS OF SURROUNDING BUILDINGS ON QUASI-STATIC WIND LOAD COMBINATIONS FOR A LOW-RISE BUILDING
}

\author{
金 容 徹*，田村幸雄** \\ Yong Chul KIM and Yukio TAMURA
}

\begin{abstract}
The primary purpose of the present work was to understand the characteristics of wind force correlations and quasi-static wind load combinations of a target model in a large group. Fluctuating pressures were integrated over the surfaces, and along-wind force, across-wind force, uplift force, along-wind overturning moment, across-wind overturning moment and torsional moment were obtained and used in the analyses. Firstly, the characteristics of wind force correlations, including the ratio of force coefficients, phase-plane expression and cross-correlation coefficients, were investigated for an isolated model and for a target model in a large group. Then, peak normal stresses in columns of a simple frame model were examined to check the wind load combination effects. Lastly, a shielding factor of a combination factor was proposed in the form of an exponential function.
\end{abstract}

Keywords : Quasi-static wind load, Surrounding buildings, Wind load combination, Combination factor, Shielding factor of combination factor 準静的風荷重，周辺建物群，風荷重の組合せ，組合せ係数，組合せ係数の Shielding factor

\section{1. はじめに}

建物の壁面に作用する変動風圧は空間積分により風方向、風直角 方向、㸚じり、あるいは鉛直方向の風力成分として建物の主要部材 に作用する。構造設計において正確に荷重効果を評価するためには、 これらの風力成分の組合せを考慮する必要がある。高層建物におけ る風荷重の組合せを検討した研究は、1970 年頃から報告されている が例えば1) 3)、低層建物における風荷重の組合せを検討した研究は比較 的最近で、主に Tamura et al. ${ }^{4)-7)}$ によって行われてきた。

Tamura et al. ${ }^{4}$-7) は中・低層建物であっても風力の風方向成分、風 直交成分、放じり成分の組合せの必要性を指摘している。Tamura et $\mathrm{al}^{4}{ }^{4)}$ は最大風方向せん断力が発生する瞬間の風圧分布と最大㸚じり モーメントが発生する瞬間の風圧分布が類似していることより、最 大風方向成分が発生する時に大きな風直交成分とねじり成分が同時 に働く可能性があることや、風方向成分と他の風力成分の組合せの 必要性を指摘した。その後、Tamura et al. ${ }^{5}$ | はフレームモデルの柱に 生じる最大軸応力度より準静的な風荷重の組合せを検討し、中・低 層建物でも風方向成分のみの風荷重評価では、最大軸応力度が 3 割 程度過小評価されることを指摘した。また、Tamura et al. ${ }^{6}$ は風荷重 の組合せにおいては風直交成分やねじり成分の正負は意味を持たず、
絶対值同士の組合せが重要であると指摘している。即ち、風方向成 分と風直交成分、あるいは風方向成分と㸚じり成分の相関は小さい が、それらの絶対值同士の相関は決して小さくなく、組み合わせを 無視すべきではないことを指摘している。さらに、Tamura et al. ${ }^{7}$ は 低・中・高層建物を対象に同様の解析を行い、最大軸応力度の過小 評価の割合を表す組合せ係数を提案した。組合せ係数は風方向成分 のみで評価された場合の柱の軸応力度の過小評価を補正するための 係数で、全風力成分が作用する時と同じ最大軸応力度が得られるよ うに、風方向風荷重と同時に作用させるべき等価な風直交方向荷重 を与える係数である。これらの結果は日本建築学会の建築物荷重指 針・同解説 $\left.(2004)^{8}\right)$ にアスペクト比が 3 より小さい建物における構造 骨組用風荷重の組合せ係数として採用されている。

ところで、これまでの風荷重の組合せに関する研究はすべて独立 した建物を対象としており、低層建物の相関および組合せに及ぼす 周辺建物群の影響を検討した研究事例は見当たらない。本研究では、 低層建物の風力成分間の相関特性および淮静的な風荷重の組合せに おける周辺建物群の影響を調べることを目的とし、種々の平面密度 をもつ周辺建物群内の低層建物の組合せ係数を検討した。
* 東京工芸大学風工学研究センター GCOE 准教授・博士 (環境学)

** 東京工芸大学工学部建築学科 教授 · 博士 (工学)
GCOE Assoc. Prof., Wind Engineering Research Center, Tokyo Polytechnic University, Ph. D.

Prof., Department of Architecture, Faculty of Engineering, Tokyo Polytechnic University, Dr. Eng. 


\section{2. 風洞実験概要}

風洞実験は東京工芸大学所有の吹き出し型乱流境界層風洞(幅 $2.2 \mathrm{~m} \times$ 高さ $1.8 \mathrm{~m} \times$ 長さ $19 \mathrm{~m})$ にて行った。対象建物として一辺 $B=0.1 \mathrm{~m}$ の立方体風圧模型を用い、周辺建物群は同じサイズの模型で再現し た。平面密度 $C_{A}$ は建物群模型の総底面積の敷地面積に対する比率で 定義されており、再現した平面密度 $C_{A}$ は $6 \% 、 11 \% 、 16 \% 、 25 \% 、 44 \%$ である。風路の前半分で接近流を作成し、後半分に建物群を配置し て風圧測定を行った。周辺建物群による影響のみを明確にするため、 先ず、建物群を配置しない状態で接近流を定義した位置 $\left(L_{f} / B=0\right)$ に単 体模型を置き、風圧測定を行った。この位置を第1対象模型位置とす る。その後、この第 1 対象模型位置 $L_{f} / B=0$ から下流側に各平面密度に 相当する周辺建物群を配置し、対象模型を下流側に移動させながら 風圧測定を行った。対象模型位置は平面密度によって異なる。風洞 内における模型配置の様子をFig.1(a)、(b)に、風圧測定模型をFig.1(c) に示し、Table 1に実験ケースをまとめて示す。

対象模型に作用寸る変動風圧を全点(125点)同時に測定しており、 サンプリング周波数は $781 \mathrm{~Hz}$ である。各チャンネルの時刻歴データ は300Hzのlow-passフィルタを通し、実時間10分相当のデータを30サ ンプル記録しており、チューブによるへルムホルツ効果はゲインと 位相の周波数特性を考慮して補正した。縮尺率は長さに対して

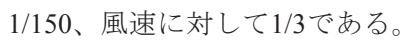

第1対象模型位置で測定した接近流は日本建築学会の建築物荷重 指針・同解説 $(2004)^{8)}$ の地表面粗度区分III(べき指数0.2)をターゲット とした乱流境界層(Fig. 2)であり、模型頂部における平均風速、乱れ の強さおよび乱れのスケールはそれぞれ $7.2 \mathrm{~m} / \mathrm{s} 、 23 \%$ と $0.5 \mathrm{~m}$ である。 本実験では、風向は壁面に正対する場合のみを対象としている。

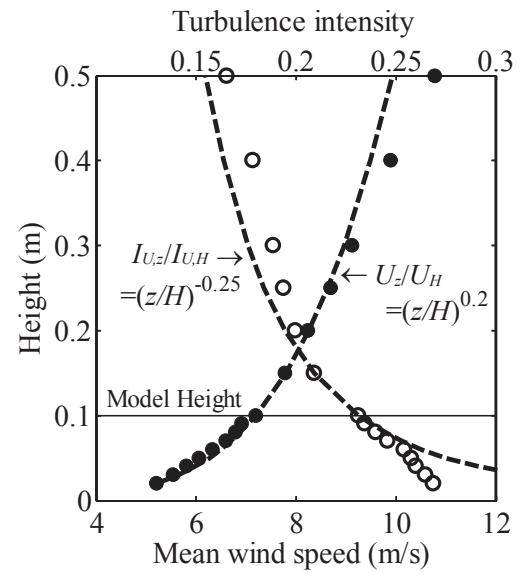

Fig. 2 Profiles of mean wind speed and turbulence intensity

\section{3. 風洞実験結果}

模型表面の風圧を空間積分して、風方向風力 $F_{X}$ 、風直角方向風力 $F_{Y}$ 、鋁直方向風力 $F_{Z 、}$ 風方向転倒モーメント $M_{Y}$ 、風直角方向転倒 モーメント $M_{X}$ およびねじりモーメント $M_{Z}$ を算出した。これらを模 型頂部の平均速度圧 $q_{H}$ より式(1) 式(6)のように無次元化した。こ こで $R=B / \sqrt{2}$ である。

$\begin{array}{lll}C_{F X}=F_{X} / q_{H} B^{2} & (1) ; & C_{F Y}=F_{Y} / q_{H} B^{2} \\ C_{F Z}=F_{Z} / q_{H} B^{2} & (3) ; & C_{M X}=M_{X} / q_{H} B^{3} \\ C_{M Y}=M_{Y} / q_{H} B^{3} & (5) ; & C_{M Z}=M_{Z} / q_{H} B^{2} R\end{array}$

\section{1. 風力成分の組合せにおける周辺建物群の影響}

Tamura et al. ${ }^{4)}$ ) 1 は独立した低層建物に対して 1 つの風力成分が最 大值をとった瞬間の他の風力成分の值、および風力成分間の相関等

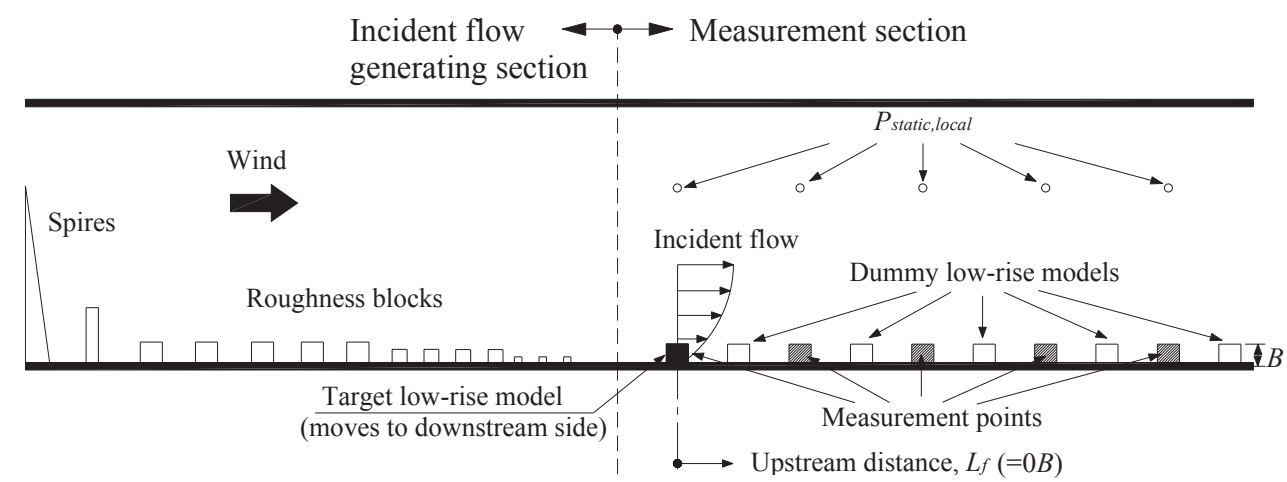

(a) Sectional view

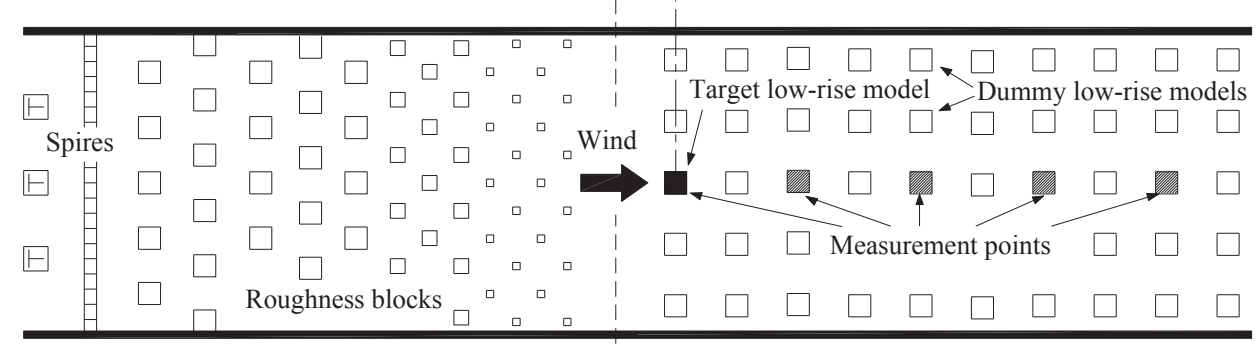

(b) Plan view

Fig. 1 Schematic of wind tunnel test

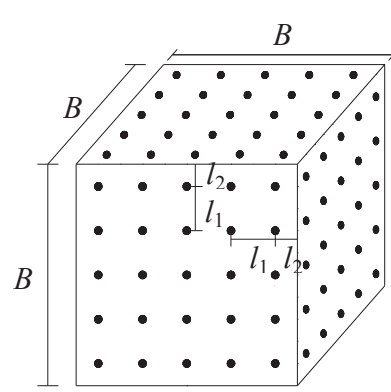

(c) Wind pressure model $\left(l_{1}=0.2 B, l_{2}=0.1 B\right)$

Table 1 Summary of wind tunnel

\begin{tabular}{|c|c|}
\hline $\begin{array}{c}\text { tests } \\
\text { density }\end{array}$ & $\begin{array}{c}\text { Meas. Range } \\
\text { (No. meas. pts) }\end{array}$ \\
\hline Isolated & - \\
\hline $6 \%$ & $0 B \sim 48 B(6)$ \\
\hline $11 \%$ & $0 B \sim 54 B(9)$ \\
\hline $16 \%$ & $0 B \sim 50 B(9)$ \\
\hline $25 \%$ & $0 B \sim 48 B(6)$ \\
\hline $44 \%$ & $0 B \sim 54 B(9)$ \\
\hline
\end{tabular}


について検討している。ここでは、単体模型に対して Tamura et al. ${ }^{4) \sim 7)}$ と同じ検討を行いその傾向を確かめた上で、周辺建物群内の対象模 型の特性について検討した。
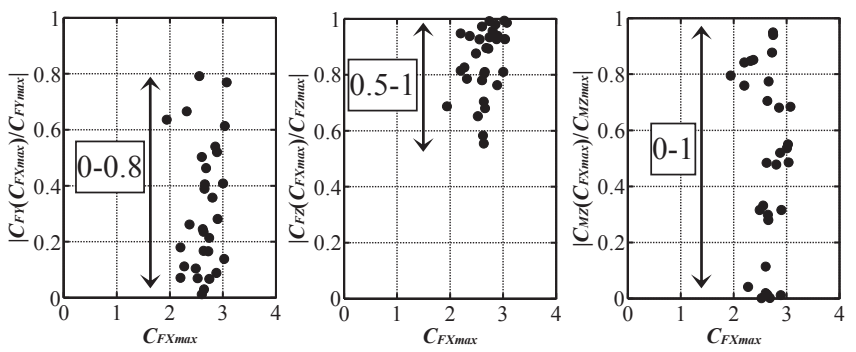

(a) $\left.\left.\left.\mid C_{F Y}\left(C_{F X \max }\right) / C_{F Y \max }\right)|(\mathrm{b})| C_{F Z}\left(C_{F X \max }\right) / C_{F Z \max }\right)|(\mathrm{c})| C_{M Z}\left(C_{F X \max }\right) / C_{M Z \max }\right) \mid$

Fig. 3 Distribution of force coefficients $C_{G i}\left(C_{F X \max }\right)$ simultaneously observed with maximum along-wind force coefficient $C_{F X \max }$ normalized by their maximum value $C_{G j \max }$ (Isolated model)
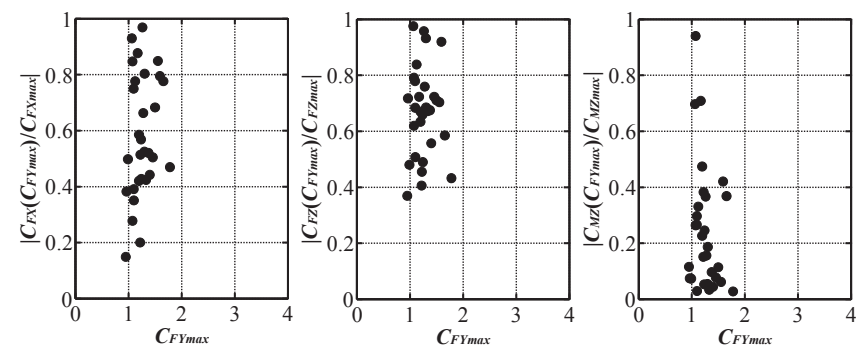

(a) $\left.\left.\left.\mid C_{F X}\left(C_{F Y \max }\right) / C_{F X \max }\right)|(\mathrm{b})| C_{F Z}\left(C_{F Y \max }\right) / C_{F Z \max }\right)|(\mathrm{c})| C_{M Z}\left(C_{F Y \max }\right) / C_{M Z \max }\right) \mid$

Fig. 4 Distribution of force coefficients $C_{G i}\left(C_{F Y \max }\right)$ simultaneously observed with maximum along-wind force coefficient $C_{F Y \max }$ normalized by their maximum value $C_{G j \max }$ (Isolated model)
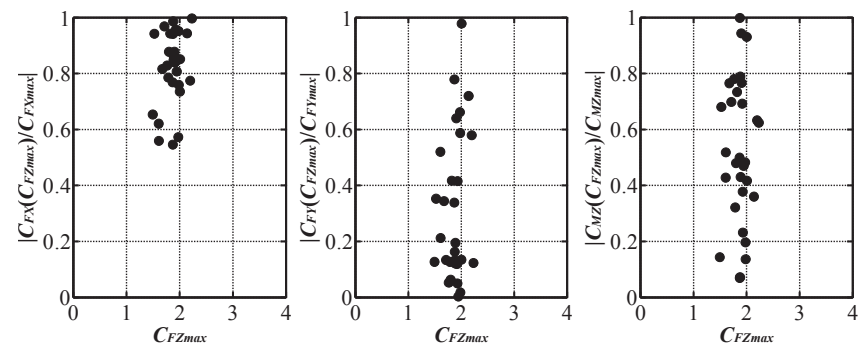

(a) $\left.\left.\mid C_{F X}\left(C_{F Z \max }\right) / C_{F X \max }\right)|(\mathrm{b})| C_{F Y}\left(C_{F Z \max }\right) / C_{F Y \max }\right) \mid\left(\right.$ (c) $\left.\mid C_{M Z}\left(C_{F Z \max }\right) / C_{M Z \max }\right) \mid$

Fig. 5 Distribution of force coefficients $C_{G i}\left(C_{F Z \max }\right)$ simultaneously observed with maximum along-wind force coefficient $C_{F Z \max }$ normalized by their maximum value $C_{\text {Gjmax }}$ (Isolated model)

Fig.3は単体模型の風方向成分 $C_{F X}$ が最大值をとった時に、同時に 観測された風直交成分 $C_{F Y}$ 鉛直成分 $C_{F Z 、}$ ねじり成分 $C_{M Z}$ の、それぞ れの最大值 $\left(C_{F Y \max } 、 C_{F Z \max } 、 C_{M Z \max }\right)$ に対する比の絶対值 $\left.\left.\left.\mid C_{F Y}\left(C_{F X \max }\right) / C_{F Y \max }\right)|、| C_{F Z}\left(C_{F X \max }\right) / C_{F Z \max }\right)|、| C_{M Z}\left(C_{F X \max }\right) / C_{M Z \max }\right) \mid$ である。 ここに、各プロットはそれぞれ実時間10分のサンプルに対する值で あり、合計 30 サンプルが示されている。風方向成分の最大值 $C_{F X m a x}$ と同時に、風直交成分 $C_{F Y}\left(C_{F X \max }\right)$ はその最大值 $C_{F Y \max }$ の $0 \sim 0.8$ 倍の值 が、鉛直成分 $C_{F Z}\left(C_{F X \max }\right)$ はその最大值 $C_{F Z \max }$ の $0.5 \sim 1$ 倍の大きめの值 が、ねじり成分 $C_{M Z}\left(C_{F X \max }\right)$ はその最大值 $C_{M Z \max }$ の $0 \sim 1$ 倍の值が観測さ れている。
Fig.4は、単体模型の風直交成分 $C_{F Y}$ が最大值をとった時に、同時に 観測される他の風力成分のそれぞれの最大值に対する比の絶対值 $\left.\left.\left.\mid C_{F X}\left(C_{F Y \max }\right) / C_{F X \max }\right)|、| C_{F Z}\left(C_{F Y \max }\right) / C_{F Z \max }\right)|、| C_{M Z}\left(C_{F Y \max }\right) / C_{M Z \max }\right) \mid$ を示す。 最大の風直交成分 $C_{F Y \max }$ 之同時に、風方向成分についてはその最大值 $C_{F X \max }$ の0.1〜 1倍の值が、鉛直成分についてはその最大值 $C_{F Z \max }$ の 0.3 ～1倍の比較的大きめの值が、ねじり成分については最大值 $C_{M Z \max }$ の $0 \sim 1$ 倍の值が観測されている。一般に、風方向成分 $C_{F X}$ と風直交成分 $C_{F Y}$ が最大值をとった時に鉛直成分 $C_{F Z}$ が大きくなることが分かる。

Fig.5は、単体模型の最大鉛直成分 $C_{F Z \max }$ と同時に観測された他の 風力成分 $\left.\left.\left.\mid C_{F X}\left(C_{F Z \max }\right) / C_{F X \max }\right)|、| C_{F Y}\left(C_{F Z \max }\right) / C_{F Y \max }\right)|、| C_{M Z}\left(C_{F Z \max }\right) / C_{M Z \max }\right) \mid$ である。風方向成分については、その最大值 $C_{F X \max }$ の 0.5 倍以上の值 が同時に観測されているが、風直交成分と㸚じり成分は、それらの 最大值 $C_{F Y \max } 、 C_{M Z \max }$ の0 1倍の值が観測されている。つまり、鉛直 成分が最大值 $C_{F Z \max }$ をとった時に、風直交成分とねじり成分について は、どのような值をも取り得る。
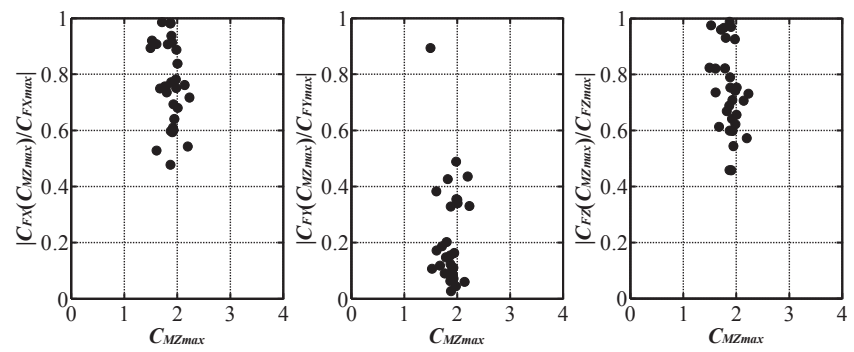

(a) $\left.\left.\left.\mid C_{F X}\left(C_{M Z \max }\right) / C_{F X \max }\right)|(\mathrm{b})| C_{F Y}\left(C_{M Z \max }\right) / C_{F Y \max }\right)|(\mathrm{c})| C_{F Z}\left(C_{M Z \max }\right) / C_{F Z \max }\right) \mid$

Fig. 6 Distribution of force coefficients $C_{G i}\left(C_{M Z \max }\right)$ simultaneously observed with maximum along-wind force coefficient $C_{M Z \max }$ normalized by their maximum value $C_{\text {Gjmax }}$ (Isolated model)

Fig.6は、単体模型の最大衫じり成分 $C_{M Z \max }$ と同時に観察された他 の 風力成分 $\left.\left.\mid C_{F X}\left(C_{M Z \max }\right) / C_{F X \max }\right)|、| C_{F Y}\left(C_{M Z \max }\right) / C_{F Y \max }\right) \mid$ 、 $\left.\mid C_{F Z}\left(C_{M Z \max }\right) / C_{F Z \max }\right) \mid$ である。衫じり成分が最大值 $C_{M Z \max }$ をとった時、 風方向成分と鉛直成分についてはそれぞれの最大值 $C_{F X \max } 、 C_{F Z \max }$ の 0.4 倍以上の大きめの值が観測される一方、風直交成分については最 大值 $C_{F Y \max }$ の0.6倍以下の小さめの值しか観測されない。最大風方向 成分 $C_{F X \max }$ 、最大風直交成分 $C_{F Y \max }$ 、最大㸚じり成分 $C_{M Z \max }$ は、常に 比較的大きめの鉛直成分 $C_{F Z}$ を伴っており、これらの単体模型に対す る結果は、Tamura et al. ${ }^{4) \rightarrow 7}$ の結果と一致している。

以上と同じように、ある風力成分 $C_{G i}$ の最大值 $C_{G i m a x}$ が生じたとき に、同時に観測される他の風力成分 $C_{G j}\left(C_{G i m a x}\right)$ のそれぞれの最大值 $C_{G j \max }$ に対する比 $C_{G j}\left(C_{G i m a x}\right) / C_{G j \max }$ の絶対值の、平面密度 $C_{A}$ による変 化を Table 2 にまとめた。添え字の $G$ は、 $F$ または $M$ を意味する。

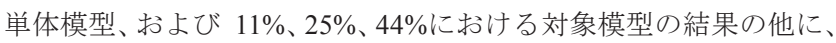
右端の欄には平面密度 $C_{A}$ の増加に伴うこれらの特性の変化傾向を 4 種類に分類して示した。分類 (1) は、下限值が一定で上限值が減少す るケース(3 ケース)、分類(2)は、下限值が減少し上限值は一定のケー ス(1 ケース)、分類 (3)は下限值と上限值が共に減少するケース (5 ケー ス)、分類(4)は、変化なし、または上限值の増加寸るケース（3 ケー ス)である。なお、Fig.6(b)のように 1 つの点が他の点と大きく離れ ているような例外的なものは無視し、全体的な傾向を捉えて大まか に分類している。ちなみに、いずれの平面密度においても第 1 対象 
模型位置での結果は、単体模型の結果とほぼ同じとなっており、ま た、第 2 対象模型位置以降では值の変化は小さい9)。Table 2 には、 これらを考慮して第 2 対象模型以降の平均值を示している。分類(1) は、 $\left|C_{M Z}\left(C_{F Y \max }\right) / C_{M Z \max }\right| 、\left|C_{F Y}\left(C_{F Z \max }\right) / C_{F Y \max }\right|$ と $\left|C_{M Z}\left(C_{F Z \max }\right) / C_{M Z \max }\right|$ で見 られており、1 つの風力成分が最大值をとった時、同時に観察され る他の風力成分がどのような值でも取り得る場合であるが、起こり える比較的大きな值が平面密度 $C_{A}$ の増加とともに減少する傾向を 示している。分類(2) は、最も多く現われており、1つの風力成分が最大值をとった時に 同時に観測される他の風力成分の全体的な特性はあまり変わらない が、平面密度 $C_{A}$ の増加とともに、比較的大きめのものが現れにくく なる傾向がある。Table 2 から分かるように、一般に、平面密度 $C_{A}$ が増加するにつれて、2 つの風力成分が同時に大きくなる可能性が 低くなっている。

Table 2 Variation of range of force components $C_{G J}\left(C_{G}\right.$ imax $)$ simultaneously observed with maximum force component $C_{G \text { imax }}$ (values in the table are normalized by $C_{G j \max }$ )

\begin{tabular}{|c|c|c|c|c|c|}
\hline & \multicolumn{4}{|c|}{ Area Density $C_{A}$} & \multirow{2}{*}{ Category } \\
\hline & Isolated & $11 \%$ & $25 \%$ & $44 \%$ & \\
\hline $\left.\mid C_{F Y}\left(C_{F X \max }\right) / C_{F Y \max }\right) \mid$ & $0-0.8$ & $0-1$ & $0-0.8$ & $0-0.6$ & (4) \\
\hline $\left.\mid C_{F Z}\left(C_{F X \max }\right) / C_{F Z \max }\right) \mid$ & $0.5-1$ & $0-1$ & $\begin{array}{ll}0 & -0.9\end{array}$ & $0-0.8$ & (3) \\
\hline $\left.\mid C_{M Z}\left(C_{F X \max }\right) / C_{M Z \max }\right) \mid$ & $0-1$ & $0-1$ & $0-1$ & $0-1$ & (4) \\
\hline $\left.\mid C_{F X}\left(C_{F Y \max }\right) / C_{F X \max }\right) \mid$ & $0.1-1$ & $0.1-1$ & $0-0.8$ & $0-0.7$ & (3) \\
\hline $\left.\mid C_{F Z}\left(C_{F Y \max }\right) / C_{F Z \max }\right) \mid$ & $0.3-1$ & $0-1$ & $0-0.8$ & $0-0.7$ & (3) \\
\hline $\left.\mid C_{M Z}\left(C_{F Y \max }\right) / C_{M Z \max }\right) \mid$ & $0-1$ & $0-0.7$ & $0-0.7$ & $0-0.7$ & (1) \\
\hline $\left.\mid C_{F X}\left(C_{F Z \max }\right) / C_{F X \max }\right) \mid$ & $0.5-1$ & $0.1-1$ & $0-0.8$ & $0-0.7$ & (3) \\
\hline $\left.\mid C_{F Y}\left(C_{F Z \max }\right) / C_{F Y \max }\right) \mid$ & $0-1$ & $0-0.9$ & $0-0.8$ & $0-0.6$ & (1) \\
\hline $\left.\mid C_{M Z}\left(C_{F Z \max }\right) / C_{M Z \max }\right) \mid$ & $0-1$ & $0-0.8$ & $0-0.7$ & $0-0.7$ & (1) \\
\hline $\left.\mid C_{F X}\left(C_{M Z \max }\right) / C_{F X \max }\right) \mid$ & $0.4-1$ & $0.4-1$ & $0.2-1$ & $0-1$ & (2) \\
\hline $\left.\mid C_{F Y}\left(C_{M Z \max }\right) / C_{F Y \max }\right) \mid$ & $0-0.6$ & $0-0.7$ & $0-0.7$ & $0-0.8$ & (4) \\
\hline $\left.\mid C_{F Z}\left(C_{M Z \max }\right) / C_{F Z \max }\right) \mid$ & $0.4-1$ & $0-0.9$ & $0-0.9$ & $0-0.8$ & (3) \\
\hline
\end{tabular}

Fig.7 に、単体模型および平面密度 $C_{A}=11 \% 、 25 \% 、 44 \%$ におり 対象模型位置 $L_{f} / B=24$ での 2 つの風力成分の位相平面表示を示す。 Fig.7(a)の単体模型における風方向成分 $C_{F X}$ と風直交成分 $C_{F Y}$ の軌跡 はほぼ円形をしており、風力成分間の相関は 0 となる。しかし、風 方向成分 $C_{F X}$ が大きな值をとった時に同時に比較的大きな風直交成 分 $C_{F Y}$ が現われる瞬間がある(Fig.7(a)の丸点)。平面密度 $C_{A}$ が増加す ると、軌跡の形状には大きな変化は見られないが、軌跡の大きさが 著しく小さくなっており、かつ風方向成分 $C_{F X}$ と風直交成分 $C_{F Y}$ が 同時に大きくなる機会は少なくなる。Fig.7(b)に示寸風方向成分 $C_{F X}$ と鉛直成分 $C_{F Z}$ の軌跡は正の勾配を持つ。特に単体模型の場合は、 これが顕著で強い相関が認められ(後述 Fig.8(b)参照)、風方向成分 $C_{F X}$ とともに鋁直成分 $C_{F Z}$ は大きくなる。この結果は Fig.3(b)の結果 ともよく一致する。平面密度 $C_{A}$ が増加するに従って勾配は変化する が、正の勾配は平面密度が増加しても保たれている。Fig.7(c)に示す 風方向成分 $C_{F X}$ と衫じり成分 $C_{M Z}$ の軌跡は、平面密度 $C_{A}$ と関係なく 楔型( 2 等辺 3 角形)をしており、㸚じり成分 $C_{M Z}$ が最大值をとった時
に風方向成分 $C_{F X}$ も最大值をとり、風方向成分 $C_{F X}$ が最大值をとっ た時には、㸚じり成分 $C_{M Z}$ はどのような值もとり得ることが分かる。 これらの結果はそれぞれ Fig.6(a)と Fig.3(c)に対応寸る。これは風方 向成分とねじり成分が同時に最大をとった時の風圧分布が類似して いる事実を報告した Tamura et al. ${ }^{4}$ の結果と符合する。また、平面密 度 $C_{A}$ の変化によって軌跡の形状には変化がないことは Table 2 の $\left|C_{M Z}\left(C_{F X \max }\right) / C_{M Z \max }\right|$ が平面密度 $C_{A}$ と関係なく同じであることと一致 する。Fig.7(d)の風直交成分 $C_{F Y}$ と鉛直成分 $C_{F Z}$ の軌跡は半円形をし ており、単体模型の場合、最大風直交成分は大きな鉛直成分を伴う ことを意味しており、Fig.4(b)とよく符合する。しかし、平面密度 $C_{A}$ が増加すると軌跡は徐々に菱形または円形に変わり、大きな值同 士が同時に発生する可能性が少なくなる。Fig.7(e)に風直交成分 $C_{F Y}$ と㸚じり成分 $C_{M Z}$ の軌跡を示す。平面密度 $C_{A}$ と関係なく傾いた棈 円形を示しており、これは後述の Fig.8(c)の相関係数の変化からも確 認できる。Fig.7(f)に鉛直成分 $C_{F Z}$ とねじり成分 $C_{M Z}$ の軌跡を示す。 単体模型の場合の楔型は平面密度の増加と共に楕円形に変わり、最 大值同士の同時出現の可能性が少なくなる。Fig.7(b)、(d)、(f)の単体 模型の結果より、既述のとおり、風方向成分 $C_{F X}$ 、風直交成分 $C_{F Y}$ 、 ねじり成分 $C_{M Z}$ が最大值をとった時に大きな鉛直成分 $C_{F Z}$ が現われ、 Fig.3(b)、4(b)、Fig.6(c)の結果と一致する。風方向成分 $C_{F X}$ と鉛直成 分 $C_{F Z}$ (Fig.7(b))、風方向成分 $C_{F X}$ と衫じり成分 $C_{M Z}$ (Fig.7(c))、風直 交成分 $C_{F Y}$ とねじり成分 $C_{M Z}$ (Fig.7(e) ) の軌跡は、平面密度 $C_{A}$ により 多少の変化は認められるが、概敉同じ形を維持している。しかし、 他の場合は平面密度 $C_{A}$ とともに円形または楕円形に変わっており、 このような変化傾向は相互相関係数からも確認できる ${ }^{9}$ 。図中の点 線は単体模型の軌跡であり、平面密度 $C_{A}$ の増加につれて、軌跡が小 さくなるとともに、風方向成分 $C_{F X}$ と鉛直成分 $C_{F Z}$ が負側に移動し ている。ちなみに平面密度 $C_{A}=44 \%$ の場合は、全ての面の風圧分布 は負のほぼ一様值となる ${ }^{10)}$ 。
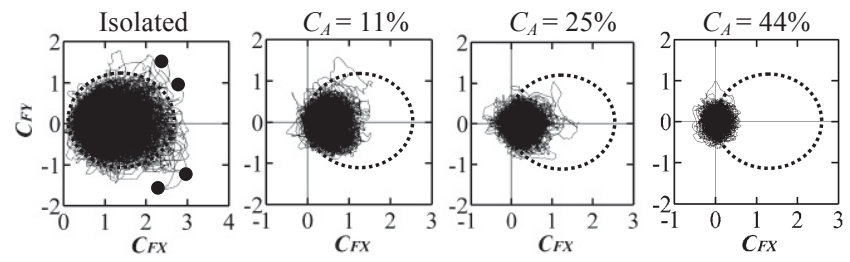

(a) $C_{F X}-C_{F Y}$
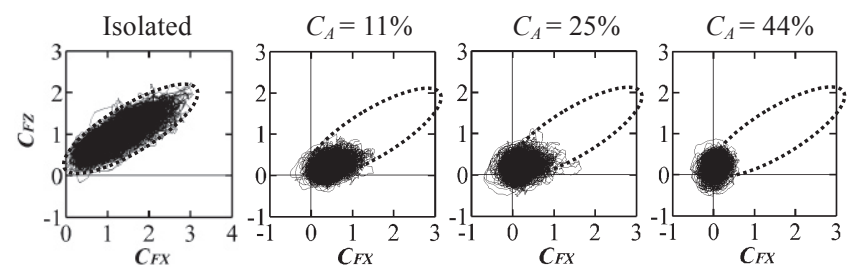

(b) $C_{F X}-C_{F Z}$
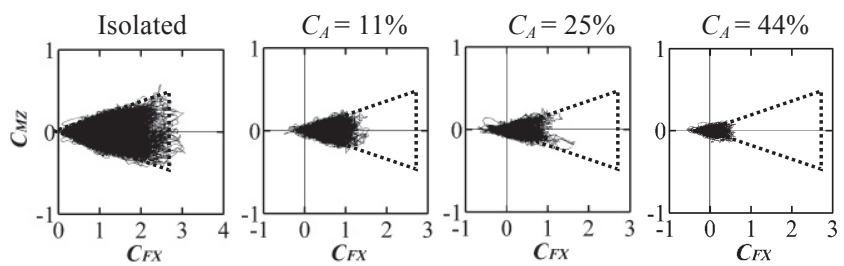

(c) $C_{F X}-C_{M Z}$ 

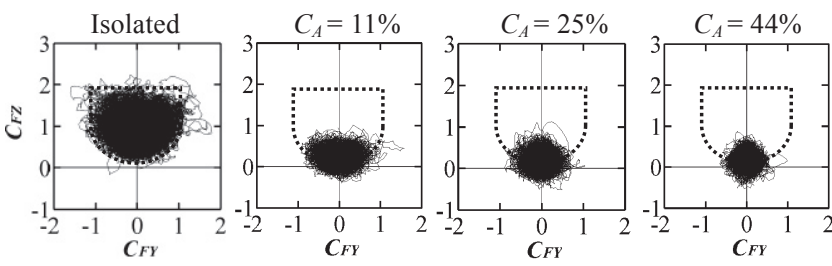

(d) $C_{F Y}-C_{F Z}$

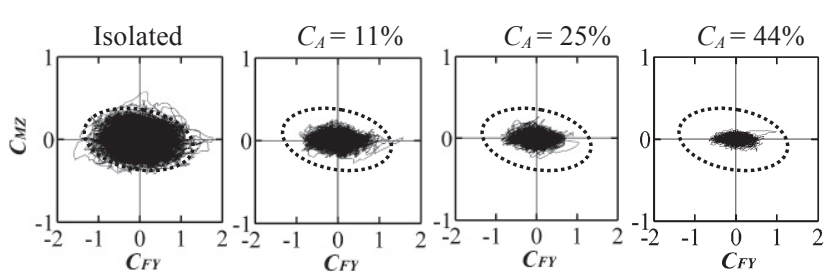

(e) $C_{F Y}-C_{M Z}$

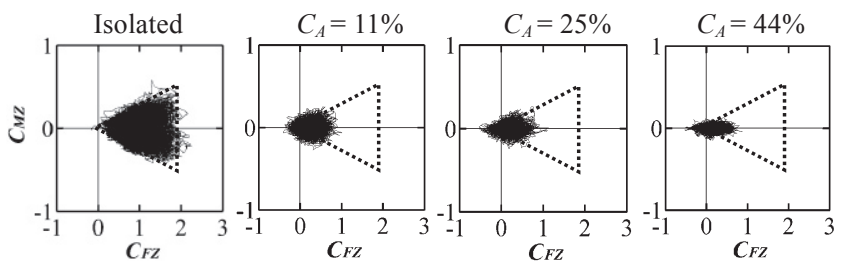

(f) $C_{F Z}-C_{M Z}$

Fig. 7 Phase-plane expression of wind force components at $L_{f} / B$ $=24$ (from the left, Isolated, $C_{A}=11 \%, C_{A}=25 \%, C_{A}=44 \%$ )

Fig. 8 に単体模型および平面密度 $C_{A}=25 \% 、 44 \%$ に対して風力成分 間の相関係数を実線で、風力成分の絶対值間の相関係数を点線で示 した。単体模型の場合、Tamura et al. ${ }^{6.7)}$ の報告のように風方向成分

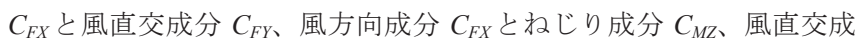

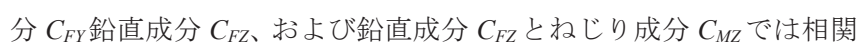
が低く、風方向成分 $C_{F X}$ と鉛直成分 $C_{F Z}$ および風直交成分 $C_{F Y}$ とねじ り成分 $C_{M Z}$ では相関が高い。しかし、絶対值の相関は全風力成分間 で高くなる ${ }^{9}$ 。Fig. $8(\mathrm{a})$ の平面密度 $C_{A}=25 \%$ と $44 \%$ の場合、風方向成 分 $C_{F X}$ と風直交成分 $C_{F Y}$ の相関 $\left(R_{C F X C F Y}\right)$ は低いが、絶対值の相関 $\left(\left.R\right|_{C F X} \|_{C F Y} \mid\right)$ は多少大きくなる。しかし、単体模型の絶対値の相関より 低く、平面密度の増加と共に相関は低くなる。このように絶対值の 相関は一般的に平面密度 $C_{A}$ の増加と共に低くなり、風直交成分 $C_{F Y}$ と鉛直成分 $C_{F Z}$ および鉛直成分 $C_{F Z}$ とねじり成分 $C_{M Z}$ の場合、平面 密度 $C_{A}=44 \%$ では絶対值の相関はほぼゼロとなる ${ }^{9}$ 。Fig.8(b)の風方 向成分 $C_{F X}$ と鋁直成分 $C_{F Z}$ では正の大きな相関が見られておりこれ は Fig.7(b) とよく対応する。風直交成分 $C_{F Y}$ と衫じり成分 $C_{M Z}$ (Fig.8(c)) は、平面密度 $C_{A}$ と無関係に高い相関が見られており、絶対 值の相関は平面密度 $C_{A}$ と関係なく一定値を示す。
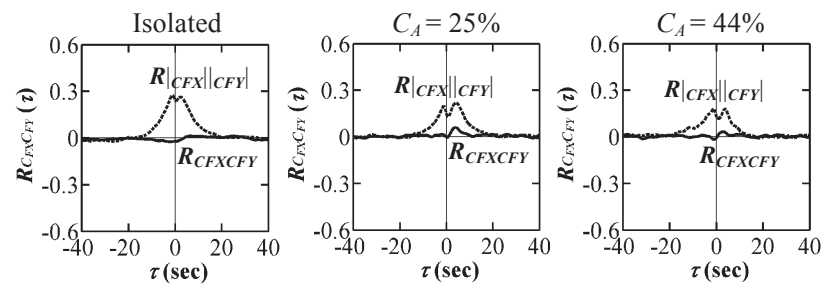

(a) $R_{C F X C F Y}\left(C_{F X}-C_{F Y}\right)$ and $\left.R\right|_{C F X}||_{C F Y} \mid\left(\left|C_{F X}\right|-\left|C_{F Y}\right|\right)$
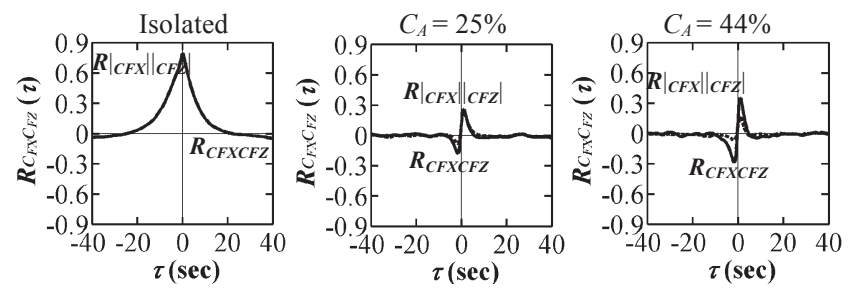

(b) $R_{C F X C F Z}\left(C_{F X}-C_{F Z}\right)$ and $R\left|{ }_{C F X}\right|{ }_{C F Z} \mid\left(\left|C_{F X}\right|-\left|C_{F Z}\right|\right)$
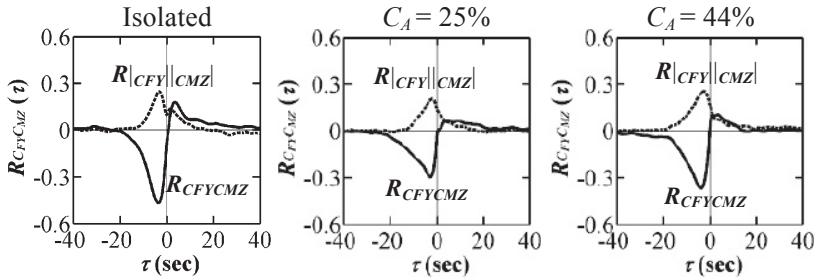

(c) $R_{C F Y C M Z}\left(C_{F Y}-C_{M Z}\right)$ and $R\left|{ }_{C F Y}\right|\left|C_{C M Z}\right|\left(\left|C_{F Y}\right|-\left|C_{M Z}\right|\right)$

Fig. 8 Cross-correlation coefficients at the same upstream distance ( $L_{\digamma}=24 B$, from the left, Isolated, $C_{A}=25 \%, C_{A}=44 \%$ )

以上をまとめると、単体模型の場合、風方向成分 $C_{F X}$ 、風直交成 分 $C_{F Y}$ 、㸚じり成分 $C_{M Z}$ が最大值をとった時に、同時に大きな鉛直 成分 $C_{F Z}$ が現われており、特に風方向成分 $C_{F X}$ と鉛直成分 $C_{F Z}$ には高 い相関が見られ、風直交成分 $C_{F Y}$ と衫じり成分 $C_{M Z}$ にも高い相関が 見られる。絶対值の相関に関しては、全ての風力成分間で高い相関 が見られた。一方、周辺建物群内の対象模型の場合、1つの風力成 分が最大值をとった時に他の風力成分が同時に大きくなりにくくな つており、絶対值の相関も平面密度 $C_{A}$ が高くなるにつれてやや小さ くなる傾向がある。

\section{2. 柱の最大応力度における周辺建物群の影響}

風力成分間の組合せを応答への影響として客観的に評価するた め、Fig.9に示すように柱と梁を持つ低層建物の応力を解析した。通 常、柱の高さの半分が支配面積となるが、簡単のためすべての荷重 $\left(F_{X} 、 F_{Y} 、 F_{Z} 、 M_{X} 、 M_{Y}\right.$ と $\left.M_{Z}\right)$ を屋根中心点に作用させて ${ }^{11)}$ 、柱の脚部 に生じる最大軸応力度 $\sigma$ にり各風力成分の組合せの影響を検討し た。今回の解析の目的は、柱応力への各風力成分の貢献度の検討で あり、応力の大きさそのものはそれほど重要ではないからである。

フレームモデルは剛な梁と4本の隅柱で構成されており、柱の剛性は 風方向成分 $F_{X}$ のみが作用寸る時に頂部変形角が $1 / 200$ に納まるよう に決定した ${ }^{11)}$ 。設計用風速は $26 \mathrm{~m} / \mathrm{s}$ であり、最大軸応力度の抽出は実 時間10分ごとに行った。また、風力の組合せの影響のみを明確にす るために固定荷重と積載荷重は作用させず、風荷重のみを考慮した。

最大軸応力度 $\sigma$ は曲げモーメントによる縁応力度と軸力による応 力度 $N / A$ との和 $\sigma(t)=M_{X}(t) / Z_{X}+M_{Y}(t) / Z_{Y}+N(t) / A$ として求めており、 $Z_{X}$ と $Z_{Y}$ は断面係数、 $A$ は断面積である。実時間10分間の時刻歴データご とに引張り応力度 $\left(\sigma^{+}\right)$と圧縮応力度 $\left(\sigma^{-}\right)$のピーク值を算出して、30 個のアンサンブル平均をとったものである。Table 3に単体模型に対 する様々な荷重条件下でのColumn 2 とColumn 3 の最大軸応力度を示 した。最大軸応力度は全風力成分考慮 $(A L L)$ では $10 \mathrm{kN} / \mathrm{cm}^{2}$ 程度、風方 向成分のみ $\left(\right.$ Only $\left.F_{X}\right)$ では $8 \mathrm{kN} / \mathrm{cm}^{2}$ 程度であり、両者の比 $(A L L) /($ Only 
$\left.F_{X}\right)$ は平均的に 1.27 となった。つまり、風力の組合せを考慮しないで、 風方向成分のみを作用させた場合、柱脚部の最大軸応力度は $27 \%$ 過 小評価される。風直交成分のみ $\left(\right.$ Only $\left.F_{Y}\right)$ による最大軸応力度は $4 \mathrm{kN} / \mathrm{cm}^{2}$ 程度で2番目に大きく、3番目は衫じり成分のみ $\left(\right.$ Only $\left.M_{Z}\right)$ に よる最大軸応力度である。鉛直方向のみ $\left(\right.$ Only $\left.F_{Z}\right) 、$ あいは $M_{X}$ と $M_{Y}$ による最大軸応力度は小さい。
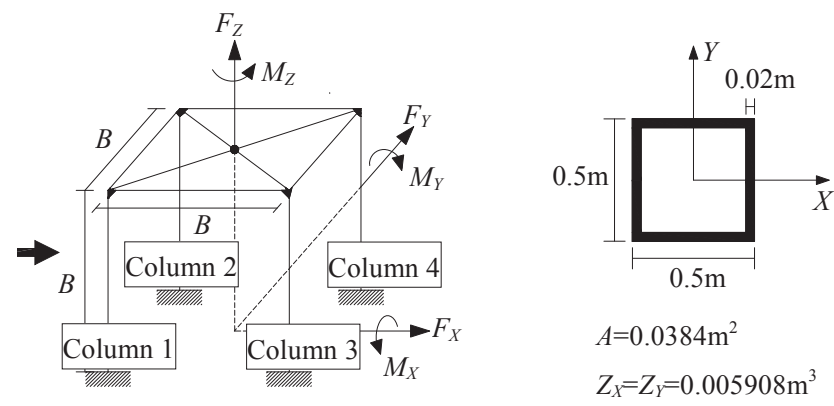

Fig. 9 Frame model with rigid connections

Table 3 Peak normal stresses of isolated model $\left(\mathrm{kN} / \mathrm{cm}^{2}\right)$

\begin{tabular}{|c|c|c|c|c|}
\hline & \multicolumn{2}{|c|}{ Column 2} & \multicolumn{2}{c|}{ Column 3 } \\
\hline & $\sigma_{\text {Isolated }}^{+}$ & $\sigma_{\text {Isolated }}^{-}$ & $\sigma_{\text {Isolated }}^{+}$ & $\sigma_{\text {Isolated }}^{-}$ \\
\hline$A L L$ & 10.5 & -9.7 & 10.0 & -10.4 \\
\hline Only $F_{X}$ & 8.1 & -7.8 & 7.8 & -8.1 \\
\hline Only $F_{Y}$ & 3.8 & -3.8 & 3.8 & -3.8 \\
\hline Only $F_{Z}$ & 0.1 & - & 0.1 & - \\
\hline Only $M_{X}$ & 0.1 & -0.1 & 0.1 & -0.1 \\
\hline Only $M_{Y}$ & 0.2 & - & - & -0.2 \\
\hline Only $M_{Z}$ & 1.4 & -1.4 & 1.4 & -1.4 \\
\hline$(A L L) /\left(\right.$ Only $\left.F_{X}\right)$ & 1.29 & 1.24 & 1.28 & 1.28 \\
\hline
\end{tabular}

建物郡内の対象模型に対しても同じ解析を行い、柱脚部に生じる 最大引張応力度 $\left(\sigma^{+}\right)$および最大圧縮応力度 $\left(\sigma^{-}\right)$の平面密度 $C_{A}$ および 対象模型設置位置 $L_{f} / B$ による変化を調べた。一例として Column 2 に生じる最大引張応力度の変化を Fig.10 に示す。

Fig.10(a) は全風力成分が作用する場合 $(A L L)$ の、Fig.10(b)は風方向 成分のみが作用する場合 $\left(\right.$ Only $\left.F_{X}\right)$ の結果であり、図中の点線は単体 模型の結果である。第 1 対象模型位置での最大引張応力度は単体模 型の結果より若干小さいが、第 2 対象模型位置以降は平面密度 $C_{A}$ が高くなるにつれて小さくなり、対象模型位置 $L_{f} B$ による変化は小 さくほぼ一定值を示している。平面密度 $C_{A}$ および対象模型位置 $L_{f} / B$ に関するこのような変化傾向は、本研究での典型的な傾向である ${ }^{12)}$

中・低層建物において、全風力成分が作用寸る場合の最大軸応力 度と同じ応力度を柱に生じさせるために風方向荷重と同時に作用さ せるべき等価な荷重 $F_{Y, E Q}$ の概念は Tamura et al. ${ }^{7}$ によって提案され ており、等価な風直交方向荷重は $F_{Y, E Q}=\gamma F_{X}$ と定義される。ここで $\gamma$ は組合せ係数と呼ばれており、Eq.(7)で定義される。

$\gamma=\left(\sigma_{A L L} / \sigma_{F X}\right)-1$

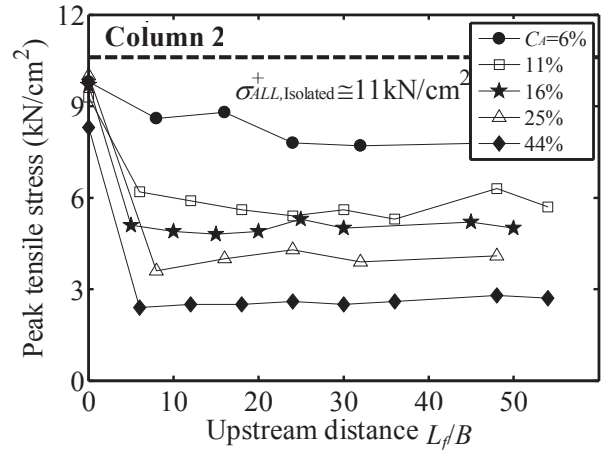

(a) $A L L$ loading condition

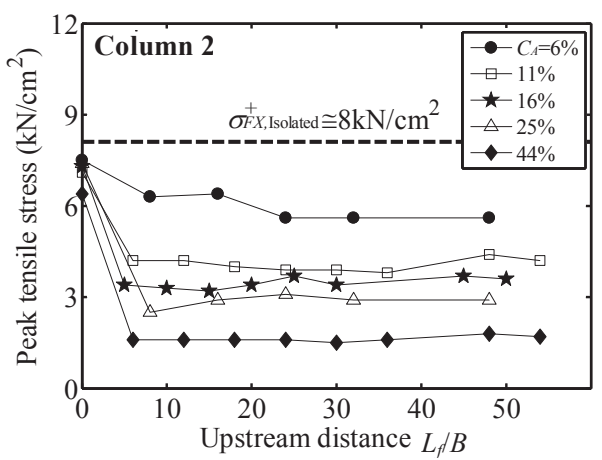

(b) Only $F_{X}$ loading condition

Fig. 10 Variation of peak tensile stresses in Column 2 for $A L L$ and Only $F_{X}$ loading conditions

したがって、前述の Table 3 の結果から、単体模型の組合せ係数 $\gamma$ は 0.27 となる。周辺建物群に囲まれた対象模型の組合せ係数より、 その shielding factor を次のように求めた。まず、周辺建物群内の対 象模型の組合せ係数を最大軸応力度の結果から求めるが、その際、 同一平面密度 $C_{A}$ では、第 2 対象模型位置以降では最大軸応力度など の対象模型位置 $L_{f} / B$ による变化が殆じないこと(例えば Column 2 の 場合、Fig.10(a) と(b)の值の比が Column 2 の組合せ係数であり、 Fig.10(a) と(b)の值の変化傾向は殆ど同じである)より、第 2 対象模型 位置から最後の対象模型位置までの組合わせ係数の平均值をその平 面密度での代表值とした。この值の単体模型の組合せ係数に対する 比を組合せ係数の shielding factor $\left(S_{\gamma}\right)$ と定義し、Fig.11 にその平面密 度 $C_{A}$ による変化を示した。組合せ係数の shielding factor $S_{y}$ は平面密 度 $C_{A}$ と共に大きくなり、その変化傾向は平面密度 $C_{A}$ のみの指数関 数として Eq.(8)のように表せる。

$S_{\gamma}=1.1 \mathrm{e}^{1.4 C A}$

組合せ係数の shielding factor $S_{\gamma}$ が平面密度 $C_{A}$ とともに大きくなるこ とは風方向成分 $F_{X}$ の相対的な寄与率が平面密度 $C_{A}$ とともに小さく なることを意味しており、風方向成分のみしか考慮しないと、平面 密度 $C_{A}$ の高い地域では、柱の軸応力度がより過小評価されることに なる。 3.1 で議論したように、風力成分間の相関は平面密度 $C_{A}$ の増 加と共に小さくなるが、風方向成分だけでなく他の風力成分の組合 せの考慮は、逆により重要となるのである。

組合せ係数の shielding factor $S_{y}$ の回帰式(Eq.(8)) と風方向成分のみ 
での最大軸応力度の結果から、全風力成分が作用する時に生じるで あろう最大軸応力度を算出することができる。これと解析より直接 に求めた最大軸応力度との比較を Fig.12 に示した。組合せ係数の shielding factor $S_{\gamma}$ は全柱の最大引張応力度と最大圧縮応力度の平均 值で求められたため、若干の差は見られるが、解析結果とよく一致 している。

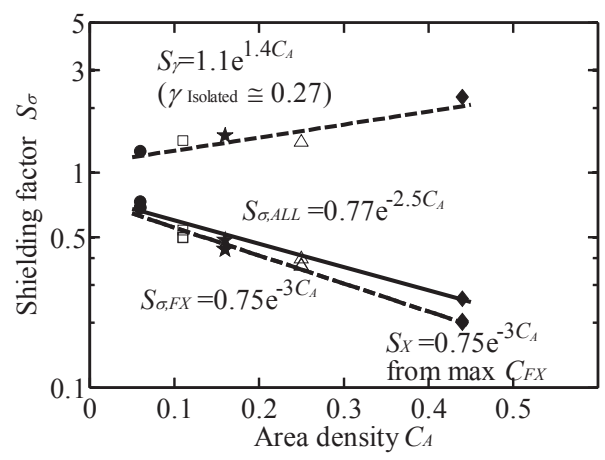

Fig. 11 Shielding factor of combination factor $\left(S_{Y}\right)$ and shielding factors of peak normal stresses $\left(S_{\sigma, A L L}, S_{\sigma, F X}\right)^{11)}$

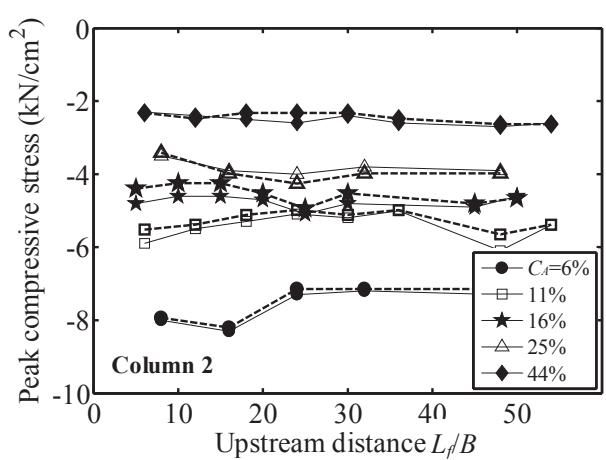

Fig. 12 Comparison of peak compressive stresses obtained from analysis (solid line) with those from regression equation of $S_{Y}$ (dotted line)

また、Fig.10に示寸単体模型と建物群に囲まれた対象模型の最大 軸応力度から、以下のEq.(9) と Eq.(10)のように、最大軸応力度の shielding factorを定義することができる。

$S_{\sigma, A L L}=\sigma_{\text {Target }, A L L} / \sigma_{\text {Isolated }, A L L}$

$S_{\sigma, F X}=\sigma_{\text {Target }, F X} / \sigma_{\text {Isolated }, F X}$

Fig.11に、全風力成分が作用した場合の結果 $\left(S_{\sigma, A L L}\right)$ と、風方向成分の みが作用した場合の結果 $\left(S_{\sigma, F X}\right)$ を、組合せ係数の shielding factor $\left(S_{\gamma}\right)$ と合わせて示した。ここでも、各平面密度に対する值は第 2 対象模型 位置以降での平均值である。全風力成分による最大軸応力度の shielding factor $S_{\sigma, A L L}$ と風方向成分の夕による最大軸応力度の shielding factor $S_{\sigma, F X}$ は、平面密度 $C_{A}$ が高くなるにつれて小さくなっ ており、組合せ係数の shielding factor $S_{y}$ とは逆の傾向を示している が、平面密度 $C_{A}$ のみの指数関数で表すことができるのは変わらな い。因みに、 $S_{\sigma, A L L}$ と $S_{\sigma, F X}$ の比が組合せ係数のshielding factor $S_{\gamma}$ となる。
点線は風方向風力の最大值より求めた shielding factor $S_{X}$ であり ${ }^{12)}$ 、風 方向成分のみによる最大軸応力度の shielding factor $S_{\sigma, F X}$ よく一致 している。Fig.11で、組合せ係数の shielding factor $S_{\gamma}$ が平面密度 $C_{A}$ と 共に大きくなることより、全風力成分に対する風方向成分の寄与率 が小さくなることが分かった。そこで、各風力成分の寄与率を調心゙ るために、全風力成分による最大軸応力度 $\left(\sigma_{A L L, \text { peak }}\right)$ 発生した時に 同時に観測される各風力成分による柱脚部の最大軸応力度 $\left(\sigma_{F, \text { peak }}\right)$ を 求め、全風力成分による最大軸応力度に対する比 $\left(\sigma_{F, \text { peak }} / \sigma_{A L L, \text { peak }}\right)$ の例 (Column 2)をFig.13に示した。

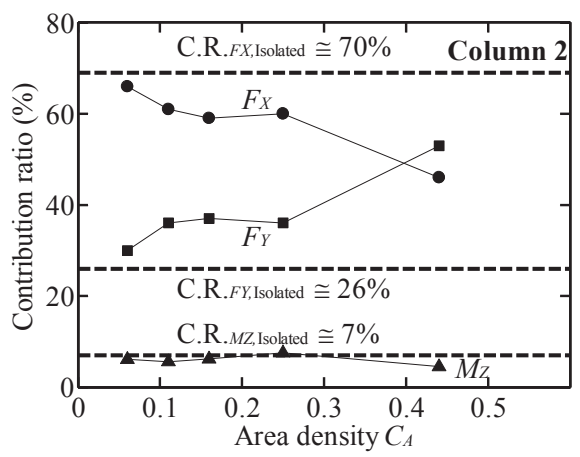

Fig. 13 Contribution ratio of $F_{X}, F_{Y}$ and $M_{Z}$

図中の点線は単体模型での結果であり、風方向成分は 70\%、風直交 成分は $26 \%$ 、叔じり成分は 7\%であった。Fig.13 から分かるように、 風方向成分の寄与率は平面密度 $C_{A}$ と共に小さくなる一方、風直交成 分は逆に大きくなる。㸚じり成分の寄与率は平面密度 $C_{A}$ と関係なく $7 \%$ である。鉛直成分 $F_{Z}$ 、転倒モーメント $M_{X}$ と $M_{Y}$ の寄与度は小さ い。建物群に囲まれた対象模型の場合、平面密度 $C_{A}$ の増加と共に各 風力成分による最大軸応力度は減少するが、風方向成分 $F_{X}$ の減少率 が他の風力成分より大きいため、風直交成分 $F_{Y}$ の寄与率が相対的に 高くなる。Fig.13 は、ほぼ同じ対象模型位置に対する結果(平面密度 $C_{A}=16 \%$ の場合は $L_{f} / B=25$ 、他の平面密度の場合は $\left.L_{f} / B=24\right)$ であるが、 他の対象模型位置および他の柱でも同様の傾向が見られた。

\section{4. まとめ}

単体模型および建物群に囲まれた対象模型に対して、風力成分間 の相関、準静的な風荷重成分の組合せを検討した。柱脚部に生じる 最大軸応力度の検討結果から、平面密度 $C_{A}$ が高くなるにつれて、風 方向荷重だけでなく他の風荷重成分との組合せが重要であることが 分かった。単体模型の場合、風方向荷重のみの考慮では、最大軸応 力度が平均的に $27 \%$ 過小評価されており、これは既往文献と同程度 の結果となった。建物群に囲まれた対象模型の場合は、過小評価さ れる割合が単体模型の場合より大きくなり、平面密度 $C_{A}=6 \%$ の場 合は $30 \%$ 程度、平面密度 $C_{A}=44 \%$ の場合は $60 \%$ であった。さらに、 組合せ係数の shielding factor $S_{\gamma}$ が、平面密度 $C_{A}$ のみの指数関数で表 わせることを示した。

風方向成分の寄与率は平面密度 $C_{A}$ が高くなるにつれて小さくな り、風直交成分の寄与率が相対的に大きくなることが分かった。し たがって、平面密度 $C_{A}$ が高い地域ほど、風荷重の組合せの必要性は 高まる。 


\section{謝辞}

本研究は文部科学省グローバル COE プログラム(風工学・教育研 究のニューフロンティア)の支援を受けた。

参考文献

1) Melbourne, W.H.: Probability distributions of response of BHP house to wind action and model comparisons, Journal of Wind Engineering and Industrial Aerodynamics 1 (2), pp. 167-175, 1975.

2) Vickery, B.J., Basu, R.I.: The response of reinforced concrete chimneys to vortex shedding, Engineering Structures 6, pp. 324-333, 1984.

3) Solari, G., Pagnini, L.C.: Gust buffeting and aeroelastic behaviour of poles and mono tubular towers, Journal of Fluid and Structures 13, pp. 877-905, 1999.

4) Tamura, Y., Kikuchi, H., Hibi, K.: Wind load combinations and extreme pressure distributions on low- rise buildings, Wind and Structures, An International Journal 3 (4), pp. 279- 289, 2000.

5) Tamura, Y., Kikuchi, H., Hibi, K.: Extreme wind pressure distributions on low-rise building models, Journal of Wind Engineering and Industrial Aerodynamics 89, pp. 1635-1646, 2001.
6) Tamura, Y., Kikuchi, H., Hibi, K.: Quasi-static wind load combinations for low- and middle-rise buildings, Journal of Wind Engineering and Industrial Aerodynamics 91, pp. 1613-1625, 2003.

7) Tamura, Y., Kikuchi, H., Hibi, K.: Peak normal stresses and effects of wind direction on wind load combinations for medium-rise buildings, Journal of Wind Engineering and Industrial Aerodynamics 96, pp. 1043-1057, 2008.

8) 日本建築学会 : 建築物荷重指針・同解説(2004), 日本建築学会, 2004.

9) Kim, Y.C., Tamura, Y., Yoshida, A.: Shielding effects on wind force correlations and quasi-static wind load combinations for low-rise building in large group, Journal of Wind Engineering and Industrial Aerodynamics 112, pp. 58-70, 2012.

10）金容徹, 吉田昭仁, 田村幸雄: 低層建物の風圧特性に対寸る上流側建物 群のフェッチの影響, 日本建築学会構造系論文集 $77,680, p p$. 1485-1492, 2012, 10.

11）菊池浩利, 田村幸雄, 日比一喜: 低層建物の風荷重の組合せに関する研 究, 日本建築学会構造系論文集 551, pp. 13-20, 2002, 1.

12）金容徹, 吉田昭仁, 田村幸雄: 低層建物の風荷重における周辺建物群の 影響, 第22回風工学シンポジウム論文集, pp. 329-334, 2012.

（2012年 9 月27日原稿受理，2013年 3 月26日採用決定） 